\title{
Identification of denitrifier strain T1 as Thauera aromatica and proposal for emendation of the genus Thauera definition
}

\author{
Bongkeun Song, Lily Y. Young and Norberto J. Palleroni
}

Author for correspondence: Norberto J. Palleroni. Tel: +19089328165 ext. 317. Fax: +19089320312. e-mail: Palleroni@aesop.rutgers.edu

Biotechnology Center for Agriculture and the Environment, Foran Hall, Rutgers University, Cook College, 59 Dudley Road, New Brunswick, NJ 089018520, USA

\begin{abstract}
Bacterial strain T1, originally isolated by P. J. Evans on the basis of its capacity for toluene degradation under denitrifying conditions, has been classified as Thauera aromatica. In a comprehensive study of strains of this species, it was found that the cells have a different type of fiagel!ar insertion from that of cells of the type species of the genus, Thauera selenatis, suggesting the convenience of an emendation of the description of the genus Thauera. Further studies on a larger collection of strains with the above characteristics may serve in the future as the basis for the creation of a new generic designation.
\end{abstract}

Keywords: Thauera aromatica, denitrification, degradation, bioremediation, environment

\section{INTRODUCTION}

In a previous communication from this laboratory (5), a strain isolated on the basis of its capacity to live at the expense of toluene under denitrifying conditions was described and labelled strain T1. Biochemical work on $\mathrm{T} 1$ showed that toluene undergoes an initial CoA attack (4), a step also found to be part of the toluene degradative pathway in other denitrifying organisms (2). Later steps in the mineralization of toluene involving ring cleavage and conversion to cell material and carbon dioxide are not known in detail at present.

The work reported here refers to the identification of strain T1 as Thauera aromatica, a species described by Anders et al. (1). Some of the phenotypic properties of the type strain of this species (K 172), which had been isolated from an enrichment culture using phenol under denitrifying conditions (17), differ from those described for the type species of the genus Thauera, Thauera selenatis (11), a fact that prompted a recommendation for an emendation of the genus description (1). In this communication, aside from presenting evidence in support of assignment of strain $\mathrm{T} 1$ to the species $T$. aromatica, we describe other differences between the two species of Thauera, suggesting the convenience of introducing additional changes in the genus definition.

The GenBank accession number for the T1 16S rRNA sequence is U95176 (Banklt104674).

\section{METHODS}

Bacterial strains. Strain $\mathbf{T} 1$ is preserved in our laboratory as a frozen suspension in liquid medium at $-70^{\circ} \mathrm{C}$. It has been deposited in the American Type Culture Collection, where it has been assigned the number ATCC 700265. Strain K 172, described as the type strain of Thauera aromatica, strain DSM 6984 and the type strain of Azoarcus evansii (K B 740) (1) were purchased from the DSMZ - Deutsche Sammlung von Mikroorganismen und Zellkulturen, Braunschweig, Germany). Strain XT (ATCC 55363), described as the type strain of Thauera selenatis $(10,11)$, was kindly sent by Joan M. Macy (La Trobe University, Australia).

Additional strains included for comparison were the type strain of Azoarcus indigens (LMG 9092, VB32) and strains of a group received from J. Tiedje, Center for Microbial Ecology of the State University of Michigan (strains Tol4, Td1, Td3, Td15 and Td21, named Azoarcus tolulyticus, and related strains MF63, MF66, MF92, MF118, MF415, MF441, BL2, BL11, 2a1, 3a1 and 7a1) (18). Sequence comparisons include information on strain $\mathrm{XXyN}$ (14) and on Burkholderia cepacia (ATCC 25416).

Culture media and growth conditions. Strains T1, K $172^{\mathrm{T}}$ and $\mathrm{XT}^{\mathrm{T}}$ were grown in the medium described by Tschech \& Fuchs (17), from which the sodium bicarbonate was omitted. Strain $\mathrm{XT}^{\mathrm{T}}$ (T. selenatis) was also grown in the medium recommended by Macy et al. (11) containing both nitrate and selenate ( $30 \mathrm{mM}$ each) as electron acceptors. Addition of selenate results in the formation of a red suspension of $\mathrm{Se}^{\mathrm{o}}$ during growth of the strain, and in the cases where the presence of selenium, which is pelleted together with the cells, interfered with some of the experiments, only nitrate was used as electron acceptor. 
Liquid media were dispensed in serum bottles, which were closed with rubber stoppers and aluminium crimps. The free and dissolved gases in the bottles were replaced by argon (5).

Description of phenotypic properties. The basic morphological characteristics of cells of strains $\mathrm{T} 1$ and $\mathrm{K} 172^{\mathrm{T}}$ were examined by phase-contrast microscopy. Flagella staining was done according to the method of Leifson (9). The analysis of the nutritional spectra of the strains was performed according to protocols designed for the aerobic pseudomonads (16), using a minimal medium to which various carbon sources were added to a $1 \mathrm{mM}$ final concentration, with the exception of cresol $(0.5 \mathrm{mM})$.

DNA isolation and purification. DNA was isolated from bacterial pellets collected in the early stationary phase. The extraction involved suspension in saline-EDTA solution $(0.15 \mathrm{M} \mathrm{NaCl}, 0.015 \mathrm{M}$ EDTA, $\mathrm{pH} 8)$, lysis by addition of SDS, and heating at $60-70^{\circ} \mathrm{C}$ for $10 \mathrm{~min}$ to inactivate the deoxyribonucleases. After cooling at room temperature, the mixture was shaken with phenol/chloroform, centrifuged, and the DNA in the aqueous supernatant was precipitated by addition of 2 vols $96 \%$ ethanol. The precipitated DNA was spooled on a glass rod, from which it was later released by dispersion into $0.1 \times \mathrm{SSC}(1 \times \mathrm{SSC}$ is $0.15 \mathrm{M}$ sodium citrate, $0.015 \mathrm{M} \mathrm{NaCl}, \mathrm{pH} 7 \cdot 0$ ). The DNA preparation was dialysed, treated with pancreatic and T1 RNases, deproteinized with Pronase, and precipitated with ethanol. When required, further deproteinizations were done by treatments with chloroform/isoamyl alcohol $(24: 1, \mathrm{v} / \mathrm{v})$, shaking for $20 \mathrm{~min}$ each time. The DNA was finally precipitated with 2-propanol, dispersed, and a convenient dilution was examined for purity at 230,260 and $280 \mathrm{~nm}$. The reading at $260 \mathrm{~nm}$ was used for quantitative estimation, by assuming an absorption coefficient of 20 .

The DNA preparations were sheared by two passages through the French press at 20000 p.s.i. (138 MPa), and adjusted to a concentration of $0.4 \mathrm{mg} \mathrm{ml}^{-1}$. Aliquots of the strains to be used as reference were labelled by nick translation using $\left[{ }^{3} \mathrm{H}\right] \mathrm{dTTP}$ and a commercial kit (Bethesda Research Labs), following the manufacturer's recommended protocol.

Determination of the DNA base composition. The $\mathrm{G}+\mathrm{C}$ contents of the DNA preparations were estimated by the procedure described by Mesbah et al. (13).

$16 S$ rRNA amplification, sequencing and phylogenetic analysis. PCR amplification of the $16 \mathrm{~S}$ rRNA gene was performed on $100 \mu \mathrm{g}$ purified DNA, using primers $27 \mathrm{~F}$ and $1522 \mathrm{R}(7)$, a GeneAmp PCR system 9600, AmpliTaq DNA polymerase (Perkin Elmer), and following the protocol included in the GeneAmp PCR reagent kit (Qiagen). The PCR products were checked by agarose gel electrophoresis, and were purified with the Qiagen PCR purification kit.

Sequence determination was performed by using internal 16S rRNA oligonucleotide sequencing primers $27 \mathrm{~F}, 357 \mathrm{~F}$, $704 \mathrm{~F}, 1242 \mathrm{~F}, 1522 \mathrm{R}, 907 \mathrm{R}, 685 \mathrm{R}$ and $321 \mathrm{R}(7)$, and the automated sequencer model ABI 373A (Perkin Elmer). Sequence homology analysis and alignment were performed by using the SUBALIGN and GDE programs for comparison with data from other members of the beta subclass of Proteobacteria, obtained from the Ribosomal Database Project (12).

DNA-DNA hybridization. The DNA-DNA hybridization experiments were done by the $S 1$ nuclease method (7), with the following modifications. Into each of $1.5 \mathrm{ml}$ Eppendorf tubes were pipetted $25 \mu 1$ formamide, $10 \mu \mathrm{l}$ labelled DNA and $50 \mu \mathrm{l}$ unlabelled DNA $\left(0.4 \mathrm{mg} \mathrm{ml}^{-1}\right)$. The tubes were placed in a special stainless steel rack with a lid pressing on the tube covers, and were immersed for $10 \mathrm{~min}$ in a water bath at $90-95^{\circ} \mathrm{C}$. The tubes were rapidly cooled, and $25 \mu 1$

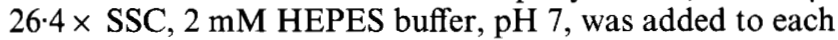
mixture. The tubes were placed again in the metallic rack and incubated for $20-22 \mathrm{~h}$ at $68 \cdot 3^{\circ} \mathrm{C}$. This hybridization temperature was chosen by subtracting $25^{\circ} \mathrm{C}$ from the $T_{\mathrm{m}}$, calculated on the basis of $66 \mathrm{~mol} \% \mathrm{G}+\mathrm{C}$, using the equation $\mathrm{GC}=2.44\left(T_{\mathrm{m}}-81.5-16.6 \log 1 \cdot 17\right)$.

All other steps of the S1 nuclease procedure followed the original description $(7,8)$.

\section{RESULTS AND DISCUSSION}

\section{Phenotypic studies of Thauera strains}

Cells of strains $\mathrm{T} 1$ and $T$. aromatica $\mathrm{K} 172^{\mathrm{T}}$, as seen under phase-contrast, are shown in Fig. 1. The morphology of the cells of the two strains taken from colonies on solid media is quite similar (Fig. 1a, b). However, the cells of strain $\mathrm{K} 172^{\mathrm{T}}$ are of very diverse morphology and appear mostly clumped when grown in liquid medium (Fig. 1c), while the morphology of T1 cells is not substantially changed under these conditions. Many cells of $\mathrm{K} 172^{\mathrm{T}}$ have refractile granules (probably poly- $\beta$-hydroxybutyrate) of different sizes, which contribute to the polymorphic characteristics of the cells. These granules are also seen in T1 cells, although in a smaller proportion.

An electron micrograph of cells of strain T1 showing the rod shape of the cells and their peritrichous flagellation has been published in a previous paper from this laboratory (5), and a similar cell is shown in Fig. 2. In the original paper describing strain $\mathrm{K} 172^{\mathrm{T}}$ (1), it is stated that the cells are slightly motile, but there is no description of the type of flagellar insertion. We have in fact observed that few cells of this strain were motile in liquid cultures of various ages, and that it is indeed difficult to observe flagellated cells in stained preparations. The cells shown in Fig. 3 have been selected out of a large number of microscopic fields. They represent a type of flagellation that has been named 'degenerately peritrichous' (3), where most flagellated cells have a single flagellum inserted at any point in the cell periphery.

The published description of strain $\mathrm{XT}^{\mathrm{T}}$ of $T$. selenatis (11) includes an electron micrograph of a cell with a single polar flagellum. This characteristic has been confirmed in our laboratory by observation of stained preparations. In young cultures of this strain, most cells are motile, and the flagellar insertion is clearly polar, with one flagellum per cell (results not shown).

\section{Growth characteristics and nutritional properties}

Strains T1 and K $172^{\mathrm{T}}$ grow on Difco Brain Heart Infusion agar plates; here the colonies become visible within 1 or $2 \mathrm{~d}$ incubation at $30^{\circ} \mathrm{C}$. Strain $\mathrm{K} 172^{\mathrm{T}}$ 

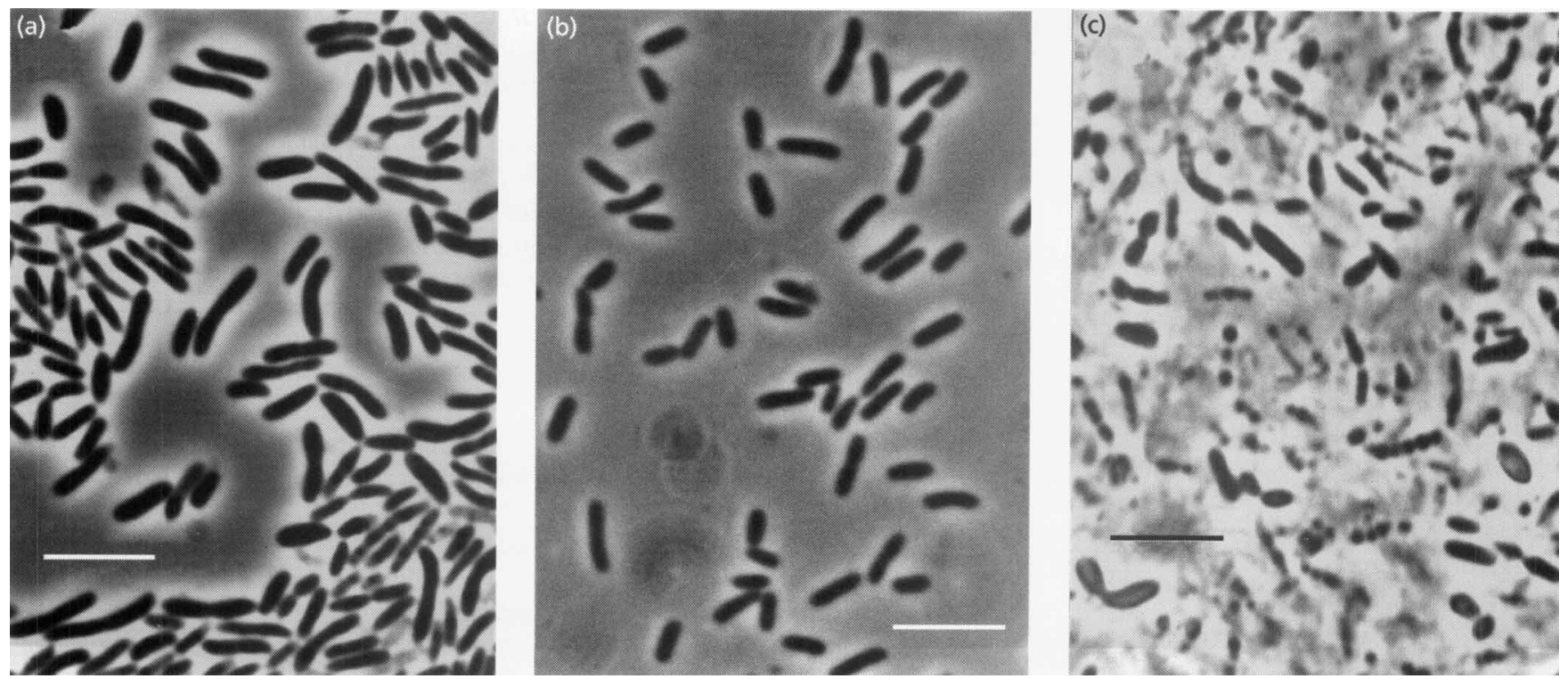

Fig. 1. (a) Cells of strain $T 1$ grown on solid medium, (b) cells of $T$. aromatica strain $K 172^{\top}$ grown on solid medium and (c) cells of strain $\mathrm{K} 172^{\top}$ grown in liquid medium under denitrifying conditions. Bars, $5 \mu \mathrm{m}$. Notice granules (poly- $\beta$ hydroxybutyrate?) inside some of the cells in (a) and (c). Phase-contrast, Leitz PL Fluotar $100 \times, 1 \cdot 32$, oil immersion.

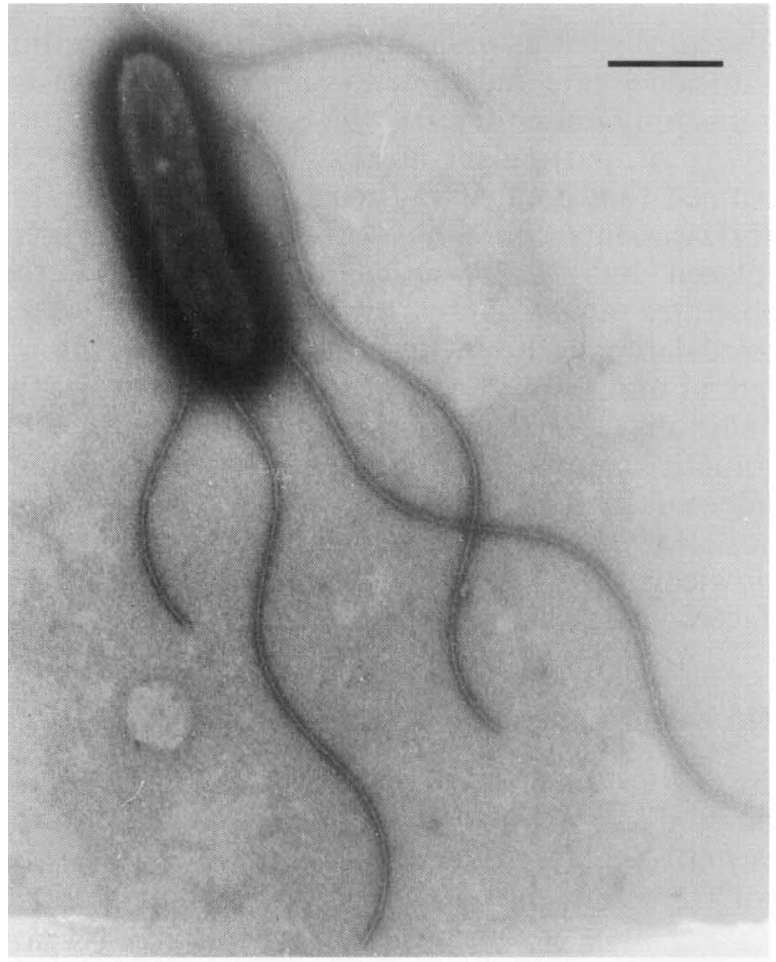

rig. L. Electron micrograpn ot a cell or strain I I sriowing the peritrichous flagellar insertion. Bar, $1 \mu \mathrm{m}$.

grows poorly on Difco nutrient agar, and T1 grows even more scantily, so that for all practical purposes, growth in this medium can be considered negative.

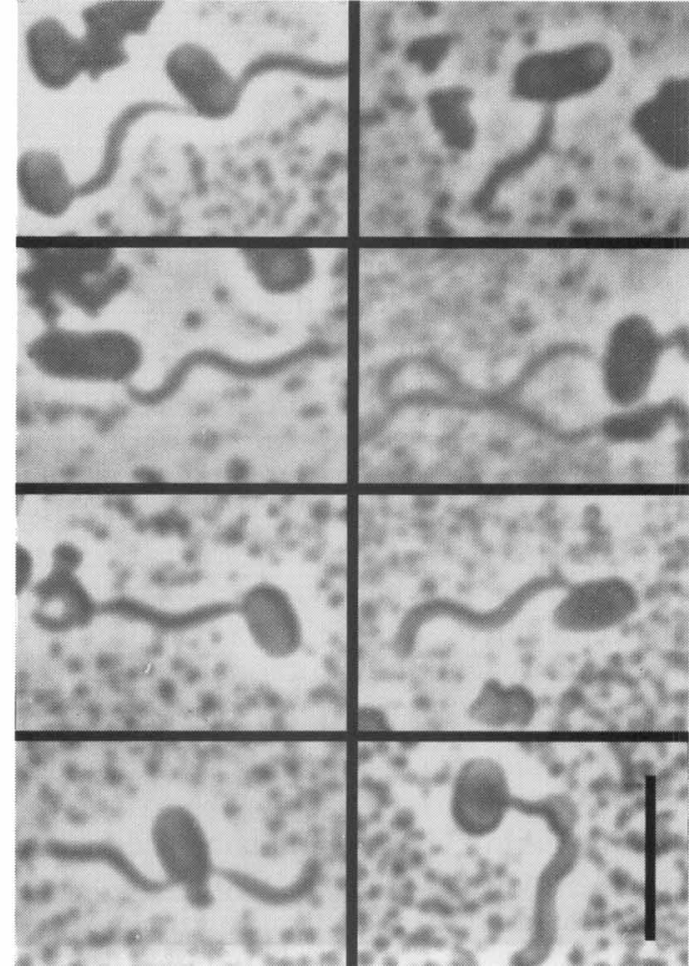

Fig. 3. Flagella stain of cells of $T$. aromatica K $172^{\top}$. Bar, $4 \mu \mathrm{m}$.

However, growth of $\mathrm{T} 1$ is considerably better on nutrient agar when the $\mathrm{pH}$ of this medium is corrected to 7.5 (initial $\mathrm{pH}$ is around 6.5 ). Growth is also 
Table 1. Nutritional differences between strains $\mathrm{T} 1$ and K $172^{\top}$ under aerobic and denitrifying conditions

+ , Normal growth; \pm , poor growth;,- no growth.

\begin{tabular}{|c|c|c|c|c|}
\hline \multirow[t]{2}{*}{ Substrate* } & \multicolumn{2}{|c|}{ Strain K 172 $^{\mathrm{T}}$} & \multicolumn{2}{|c|}{ Strain T1 } \\
\hline & $\mathbf{O}_{2}$ & $\mathrm{NO}_{3}^{-}$ & $\mathbf{O}_{2}$ & $\mathrm{NO}_{3}^{-}$ \\
\hline Adipate & \pm & \pm & - & \pm \\
\hline 3-Aminobenzoate & - & \pm & - & - \\
\hline 4-Aminobenzoate & - & - & \pm & - \\
\hline$m$-Cresol $(0.5 \mathrm{mM})$ & - & \pm & - & \pm \\
\hline$p$-Cresol $(0.5 \mathrm{mM})$ & \pm & + & \pm & \pm \\
\hline Heptanoate & - & \pm & - & \pm \\
\hline Hydroxycinnamate & + & \pm & - & - \\
\hline 2-Hydroxybenzoate & - & \pm & - & - \\
\hline 4-Hydroxylcinnamate & + & + & + & - \\
\hline Isovalerate & - & \pm & - & - \\
\hline L-Leucine & \pm & \pm & - & \pm \\
\hline D-Mandelate & \pm & + & + & + \\
\hline L-Mandelate & \pm & + & + & + \\
\hline L-Ornithine & - & + & - & + \\
\hline Phenol & - & + & - & - \\
\hline Protocatechuate & - & + & - & + \\
\hline L-Serine & - & \pm & - & \pm \\
\hline Toluene & - & + & - & + \\
\hline
\end{tabular}

*1 mM concentration, except for the cresols.

noticeably better at $\mathrm{pH} 8.5$ than at $\mathrm{pH} 6.5$, but not as good as at $\mathrm{pH} 7 \cdot 5$. This behaviour of strain $\mathrm{T} 1$ is useful both from the point of view of strain characterization and to monitor cultures for the presence of common heterotrophic contaminants.

A nutritional screening of strains $\mathrm{T} 1$ and $T$. aromatica $\mathrm{K} 172^{\mathrm{T}}$ has shown that both strains use for growth the following substrates under either aerobic or denitrifying conditions: acetate, benzaldehyde, benzoate, butyrate, ethanol, fumarate, L-glutamate, glutarate, 4-hydroxybenzoate, 4-hydroxyphenylacetate, DL-lactate, L-malate, 2-oxoglutarate, phenylacetate, L-phenylalanine, propionate, pyruvate, succinate, valerate and vanillate.

$\beta$-Alanine, $\mathrm{D}$-alanine, $\mathrm{L}$-asparagine, $\mathrm{D}$ - and $\mathrm{L}$-aspartate, benzyl alcohol, caproate, 4-chlorobenzoate, $o$-cresol, cyclohexane-carboxylate, 2-fluorobenzyl alcohol, Dfructose, 3-hydroxybenzyl alcohol, 5-hydroxylvanillate, isovanillate, $\mathrm{D}$-lactose, maltose, nicotinate, phthalate, pimelate, L-proline, quinate, D-ribose, $m$ tartrate, $o$-toluate, $m$-toluate and $\mathrm{L}$-valine are not used by either strain under aerobic or anaerobic conditions.

It is evident that the two strains are very similar in their nutritional properties. Table 1 shows a list of substrates giving different results depending on the strains or the conditions. Some of these substrates are taxonomically useful for the differentiation of the two strains. As shown in Table 1, strain $\mathrm{K} 172^{\mathrm{T}}$ has a higher nutritional
Table 2. Levels of $16 \mathrm{~S}$ rRNA sequence similarities for species of the genera Thauera and Azoarcus and the species $B$. cepacia in the beta subclass of Proteobacteria

The strain numbers are: $1, T$. aromatica $\mathrm{K} 172^{\mathrm{T}} ; 2, \mathrm{~T} 1 ; 3, \mathrm{mXyN} 1$; 4, . selenatis $\mathrm{XT}^{\mathrm{T}} ;$ 5, A. indigens $\mathrm{LMG}$ 9092; 6, $A$. evansii $\mathrm{KB}$ $740^{\mathrm{T}} ; 7, A$. tolulyticus Tol4; and 8, B. cepacia ATCC 25416 . The two triangles enclose groups of $16 \mathrm{~S}$ rRNA similarity values among species of Thauera and Azoarcus, respectively.

\begin{tabular}{|c|c|c|c|c|c|c|c|}
\hline Strain & 1 & 2 & 3 & 4 & 5 & 6 & 7 \\
\hline 1. & 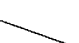 & & & & & & \\
\hline 2. & 99.7 & & & & & & \\
\hline 3. & $99 \cdot 6$ & 99.6 & & & & & \\
\hline 4. & $97 \cdot 6$ & 97.6 & $98 \cdot 0$ & & & & \\
\hline 5. & $94 \cdot 8$ & $94 \cdot 0$ & $94 \cdot 2$ & $94 \cdot 1$ & & & \\
\hline 6. & 93.6 & $93 \cdot 6$ & 93.9 & $93 \cdot 6$ & $95 \cdot 0$ & & \\
\hline 7. & $93 \cdot 2$ & $93 \cdot 2$ & $93 \cdot 5$ & $93 \cdot 4$ & $95 \cdot 0$ & $98 \cdot 6$ & \\
\hline 8. & $87 \cdot 8$ & $87 \cdot 8$ & $88 \cdot 0$ & $87 \cdot 5$ & $88 \cdot 8$ & $86 \cdot 7$ & $86 \cdot 4$ \\
\hline
\end{tabular}

versatility, as indicated by its capacity of weak growth at the expense of 3-aminobenzoate, hydroxycinnamate, 2-hydroxybenzoate and isovalerate, and good growth on phenol under denitrifying conditions.

Substrates such as $m$-cresol, heptanoate, L-ornithine, protocatechuate and toluene support growth of both strains only under denitrifying conditions. This property is of particular interest, since it is generally assumed that denitrifying bacteria can use the same substrates in the presence of air as when oxygen is replaced by nitrate, with the exception of those substrates attacked by oxygenases, which require molecular oxygen. In fact, Table 1 shows the preferential utilization of 12 substrates under denitrifying conditions and that, remarkably, six of them are aromatic compounds. The negative results obtained under anaerobic conditions perhaps suggest the presence of oxygen-sensitive permease systems, but to our knowledge this interesting phenomenon lacks a satisfactory biochemical explanation.

\section{DNA base composition of Thauera strains}

The $\mathrm{G}+\mathrm{C}$ content of the genomic DNA of strains T1 and $\mathrm{K} 172^{\mathrm{T}}$ was found to be 67.9 and $68.1 \mathrm{~mol} \%$, respectively. The value reported for $T$. selenatis is 66 mol $\%$, as determined by the DNA melting point (11).

\section{5 rRNA gene sequence studies}

The sequence of T1 16S rRNA, determined as indicated in Methods, was deposited in GenBank and received the accession number U95176 (BankIt104674). Values obtained in the comparative study of our sequences with those of known organisms are represented in Table 2 and are used for the construction of the phylogenetic tree of Fig. 4. 


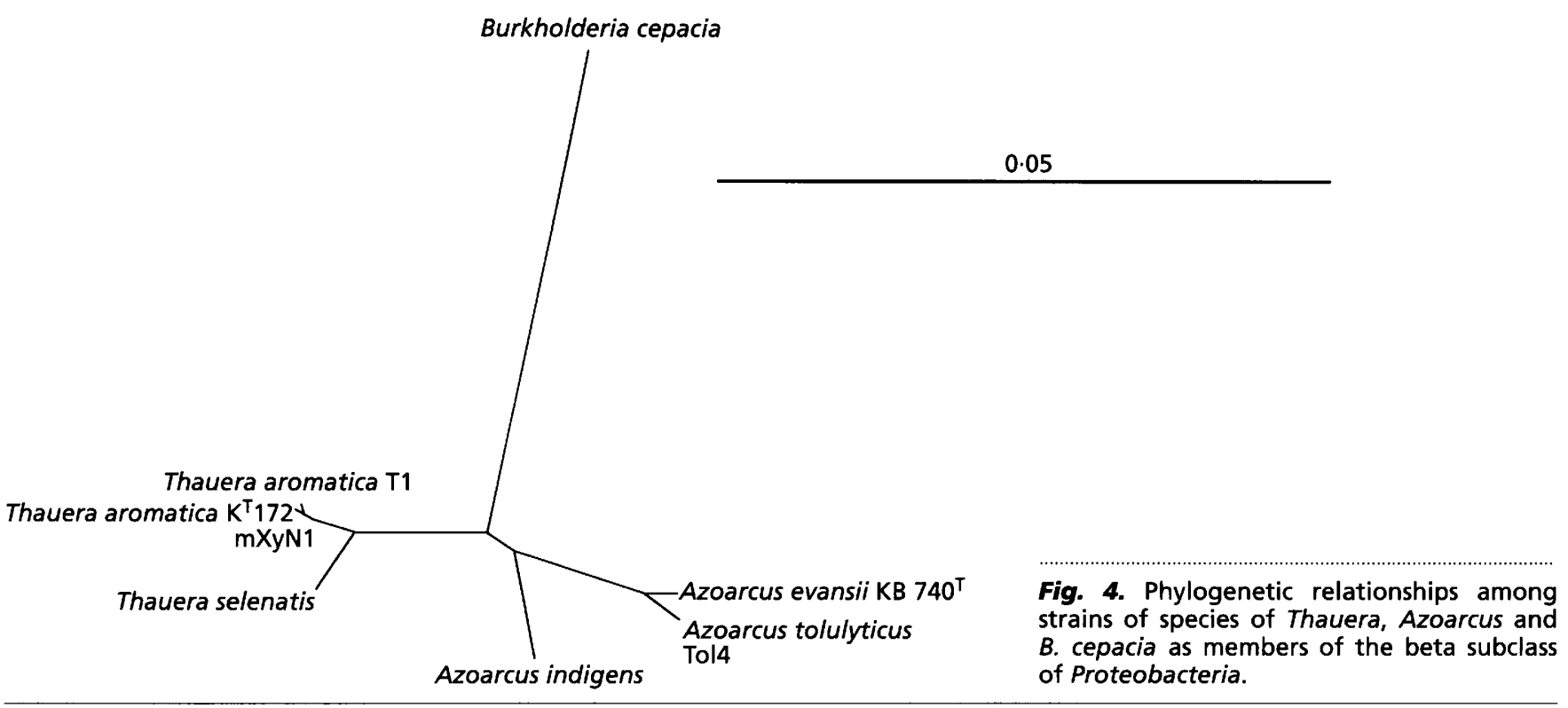

Table 3. DNA sequence similarities between strain $\mathrm{T} 1$ and other toluene-degrading bacterial strains

\begin{tabular}{|lc|}
\hline Organism & Similarity (\%) \\
\hline T. aromatica ${\mathrm{K} 172^{\mathrm{T}}}^{\mathrm{T}}$ & $76 \cdot 5^{*}$ \\
T. selenatis $\mathrm{XT}^{\mathrm{T}}$ & $23 \cdot 0$ \\
Strains assigned to $T$. tolulyticus and & $0 \cdot 0-14 \cdot 0$ \\
related organisms (strains Tol4, TD3, & \\
TD15, TD21, MF63, MF66, MF92, & \\
MF118, MF415, MF441, BL2, BL11, & \\
2a1, 3a1 and 7a1) & \\
A. evansii KB 740 , DSM 6898 & $0 \cdot 0$ \\
A. indigens LMG 9092 & $5 \cdot 0$ \\
\hline
\end{tabular}

* Value obtained using T1 DNA as reference; the reciprocal reaction, using K $172^{\mathrm{T}}$ DNA as reference, gave $78.7 \%$ similarity.

\section{DNA hybridization experiments}

The DNA similarity values obtained by hybridization, using the $\mathrm{S} 1$ nuclease methodology, are summarized in Table 3. Low similarities have been observed with various members of the beta subclass of the Proteobacteria, with the exception of $T$. aromatica $\mathrm{K} 172^{\mathrm{T}}$. The similarity value using T1 as reference DNA is in good agreement with the value obtained in the reciprocal reaction, with $\mathrm{K} 172^{\mathrm{T}} \mathrm{DNA}$ as reference. A moderate similarity value $(23 \%)$ was detected between $\mathrm{T} 1$ and $T$. selenatis strain $\mathrm{XT}^{\mathrm{T}}$.

\section{General conclusions and proposal for emendation of the genus Thauera definition}

The evidence presented here indicates that strain $\mathrm{T} 1$ belongs to the same species as $\mathrm{K} 172^{\mathrm{T}}$. Additional information obtained by means of an electrophoretic analysis of DNA restriction fragments by PFGE (15) and of protein patterns in polyacrylamide gels (6) clearly showed similarities between strains $\mathrm{T} 1$ and $\mathrm{K}$ $172^{\mathrm{T}}$ (results not shown).

Assignment of strain $\mathrm{K} 172^{\mathrm{T}}$ to the genus Thauera (1) has not taken into consideration the differences in flagellar insertion between strain $\mathrm{K} 172^{\mathrm{T}}$ and strain $\mathrm{XT}^{\mathrm{T}}$ of $T$. selenatis. Strain T1 flagellation is clearly peritrichous (Fig. 2), and $\mathrm{K} 172^{\mathrm{T}}$ has a type of flagellation that has been named 'degenerately peritrichous' (3). These facts represent a discrepancy between the phenotype of the T. aromatica strains and that of $T$. selenatis. Two alternatives could solve this situation. One would be the creation of a new genus for $\mathrm{K} 172^{\mathrm{T}}$ and $\mathrm{T} 1$, a criterion supported by the somewhat large genetic distance between each of these two strains and $T$. selenatis (Fig. 4). However, we are inclined to follow the second alternative of allocating, for the time being, the three strains to the genus Thauera in view of the low number of strains under consideration. Further studies on additional strains of this group may justify assignment of the peritrichously flagellated strains to a different genus. This conservative criterion, however, implies the proposal of an emendation of the Thauera definition (11) and of its later modification (17). The emendation consists of accepting within the genus both types of flagellar insertion, polar monotrichous and degenerately peritrichous.

Because of their ability to degrade aromatic compounds under denitrifying conditions, the genera Thauera and Azoarcus in the beta subclass of the Proteobacteria include strains of environmental importance that can be isolated from distantly located natural sites. Even though members of these two taxa appear to be similar in a number of phenotypic properties, the genomic diversity of Azoarcus is considerable, suggesting the need for the creation of 
several new species (B. Song \& N. J. Palleroni, unpublished observations). A similar situation probably holds true for the genus Thauera. Additional information is being obtained in our laboratory from the study of these strains and others isolated on the basis of similar physiological properties. These studies are now in progress and thus far they suggest that the creation of additional internal subdivisions under different generic designations may in fact become the most satisfactory solution from the taxonomic viewpoint (B. Song, M. Häggblom \& N. J. Palleroni, unpublished). At the moment, however, such conclusions seem premature, and one of the purposes of the present communication has been to assign a formal name to a strain which is being intensively studied in our laboratory, and also, more importantly, to underline the fact that an analysis of the microbial degradation of some aromatic compounds under denitrifying conditions may reveal a considerable degree of prokaryotic diversity.

\section{ACKNOWLEDGEMENTS}

This work was supported in part by grants from NSF (MCB 95-0713202), DARPA (N000-1492-J1888) and ONR (N00014931-11008). We want to thank John Urbance for helpful suggestions and criticism.

\section{REFERENCES}

1. Anders, H.-J., Kaetzke, A., Kămpfer, P., Ludwig, W. \& Fuchs, G. (1995). Taxonomic position of aromatic-degrading denitrifying pseudomonad strains K 172 and KB 740 and their description as new members of the genera Thauera, as Thauera aromatica sp. nov., and Azoarcus, as Azoarcus evansii sp. nov., respectively, members of the beta subclass of the Proteobacteria. Int J Syst Bacteriol 45, 327-333.

2. Chee-Sanford, J. C., Frost, J. W., Fries, M. R., Zhou, J. Z. \& Tiedje, J. M. (1996). Evidence for acetyl coenzyme A and cinnamoyl coenzyme $\mathrm{A}$ in the anaerobic toluene mineralization pathway in Azoarcus tolulyticus Tol-4. Appl Environ Microbiol 62, 964-973.

3. Davis, D. H., Doudoroff, M., Stanier, R. Y. \& Mandel, M. (1969). Proposal to reject the genus Hydrogenomonas: taxonomic implications. Int J Syst Bacteriol 19, 375-390.

4. Evans, P. J., Ling, W., Goldschmidt, B., Ritter, E. R. \& Young, L. Y. (1992). Metabolites formed during anaerobic transformation of toluene and $o$-xylene and their proposed relationship to the initial steps of toluene mineralization. Appl Environ Microbiol 58, 496-501.
5. Evans, P. J., Mang, D. T., Kim, K. S. \& Young, L. Y. (1991). Anaerobic degradation of toluene by a denitrifying bacterium. Appl Environ Microbiol 57, 1139-1145.

6. Jackman, P. J. H. (1985). Bacterial taxonomy based on electrophoretic whole-cell protein patterns. In Chemical Methods in Bacterial Systematics, pp. 115-129. Edited by M. Goodfellow \& D. E. Minnikin. London: Academic Press.

7. Johnson, J. L. (1994). Similarity analysis of DNAs. In Methods for General and Molecular Bacteriology, pp. 655-682. Edited by P. Gerhardt, R. G. E. Murray, W. A. Wood \& N. R. Krieg. Washington, DC: American Society for Microbiology.

8. Johnson, J. L. \& Palleroni, N. J. (1989). Deoxyribonucleic acid similarities among Pseudomonas species. Int J Syst Bacteriol 39, 230-235.

9. Leifson, E. (1951). Staining, shape, and arrangement of bacterial flagella. J Bacteriol 62, 377-389.

10. Macy, J. M., Michel, T. A. \& Kirsch, D. G. (1989). Selenate reduction by a Pseudomonas species: a new mode of anaerobic respiration. FEMS Microbiol Lett 61, 195-198.

11. Macy, J. M., Rech, S., Auling, G., Dorsch, M., Stackebrandt, E. \& Sly, L. I. (1993). Thauera selenatis gen. nov., sp. nov., a member of the beta subclass of Proteobacteria with a novel type of anaerobic respiration. Int $J$ Syst Bacteriol 43, 135-142.

12. Maidak, B. L., Olsen, G. J., Larsen, N., Overbeck, R., McCaughey, M. J. \& Woese, C. R. (1996). The ribosomal database project. Nucleic Acids Res 24, 82-85.

13. Mesbah, M., Premachandran, U. \& Whitman, W. B. (1989). Precise measurement of the $\mathrm{G}+\mathrm{C}$ content of deoxyribonucleic acid by high-performance liquid chromatography. Int J Syst Bacteriol 39, 159-167.

14. Rabus, R. \& Widel, F. (1995). Anaerobic degradation of ethylbenzene and other aromatic hydrocarbons by new denitrifying bacteria. Arch Microbiol 163, 96-103.

15. Rainey, P. B., Thompson, I. P. \& Palleroni, N. J. (1994). Genome and fatty acid analysis of Pseudomonas stutzeri. Int J Syst Bacteriol 44, 54-61.

16. Stanier, R. Y., Palleroni, N. J. \& Doudoroff, M. (1966). The aerobic pseudomonads: a taxonomic study. J Gen Microbiol 43, 159-271.

17. Tschech, A. \& Fuchs, G. (1987). Anaerobic degradation of phenol by pure cultures of newly isolated denitrifying pseudomonads. Arch Microbiol 148, 213-217.

18. Zhou, J., Fries, M. R., Chee-Sanford, J. C. \& Tiedje, J. M. (1995). Phylogenetic analyses of a new group of denitrifiers capable of anaerobic growth on toluene and description of Azoarcus tolulyticus sp. nov. Int $J$ Syst Bacteriol 45, 500-506. 